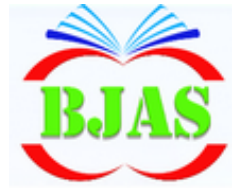

ISSN 1814 - 5868
Available online at http://bjas.bajas.edu.iq https://doi.org/10.37077/25200860.2020.33.1.12 College of Agriculture, University of Basrah

Basrah J. Agric. Sci. 33(1): 159-171, 2020

\section{Basrah Journal of Agricultural Sciences}

E-ISSN: 2520-0860

\title{
Effect of Dietary Supplementing Cumin (Cuminum cyminum L.) on Meat Traits of the Broiler Chicks
}

\author{
Rauf H. Majid ${ }^{1}$, Tariq Kh. M. Albashr ${ }^{2}$, Arazu A. Hamma ${ }^{1}$ \& Zaid Kh. Khidhir ${ }^{*}$ \\ ${ }^{1}$ Department of Animal Sciences, College of Agricultural Engineering Sciences, Sulaimani \\ University, Iraq \\ ${ }^{2}$ Department of Food Science, College of Agriculture, Tikrit University, Iraq \\ *Corresponding author:zaid.khzir@ univsul.edu.iq
}

Received 22 March 2020; Accepted 27 April 2020; Available online 27 June 2020

\begin{abstract}
This study was conducted to evaluate the dietary using of cumin as feed supplement on meat quality traits of the broiler chicken. Eight-day old broiler divided into 4 groups, 3 replicates ( 8 chicks/replicate) each for 45 days. Treatments included; (T1), basal diet without cumin or control, (T2), basal diet with 3 g. cumin. $\mathrm{kg}^{-1}$ of diet, (T3), basal diet with $6 \mathrm{~g}$. cumin. $\mathrm{kg}^{-1}$ of diet, (T4), basal diet with $9 \mathrm{~g}$. cumin. $\mathrm{kg}^{-1}$ of diet. At the end of this experiment after slaughtering all the chicks, samples were taken from breast and thigh meat. Results revealed that cumin supplementation did not significantly $(\mathrm{p}<0.01)$ affect moisture percentages of breast meat and protein percentages of thigh meat. Results also showed that use basal diet with 3 and 6 g.cumin. $\mathrm{kg}^{-1}$ of diet significantly $(\mathrm{p}<0.01)$ impact on meat water holding capacity and cooking loss percentages, while different cumin level impact on fat, ash percentages, $\mathrm{pH}$ value, TBA, TVB.N values, metmyoglobin, myoglobin value, copper, nickel, zinc, iron, magnesium, phosphorus and calcium concentrations of thigh meat, as well as iron, magnesium, phosphorus, sodium and calcium concentrations of breast meat. Results conclude that using cumin as feed supplement in 3,6 and 9 g. $\mathrm{kg}^{-1}$ level, improve most chemical and physical traits of meat.
\end{abstract}

Keywords: Cumin, feed additive, Broiler chicks, Meat traits.

\section{Introduction}

The source of cumin is the herb Cuminum cyminum, which grows in the eastern Mediterranean to South Asia. Ground-based, especially in India, in addition to dietary uses of cumin, it has traditional medicinal uses, especially in India, where it treats digestive disorders such as diarrhea and indigestion Srinivasan (2018). Studies conducted in several countries, including India, indicated that cumin oil has a high antioxidant effect because it contains flavonoids, especially monoterpene, apigenin and luteolin, which are found in seeds (Lassak, 1996; De Martino, et al., 2009). Cumin oil is used in some cases as an internal or external sterilizer, pain reliever, inflammatory control, hemolysis, cessation of enzymes, stomach stimulant, and has been 
widely used in ancient Iranian medicine, especially in the treatment of gastrointestinal disorders, gynecological diseases, respiratory system, toothache, diarrhea and epilepsy (Johri, 2011). The use of antibiotics to stimulate growth in poultry led to an increase in production, but the World Health Organization and for the purpose of maintaining public health and the absence of resistance to these antibiotics in the human body, has recommended to find alternatives to antibiotics, especially natural ones such as plant extracts that can add to broiler rations (Mahmood et al., 2015; Akyildiz \& Denli, 2016; Diaz Carrasco et $a l ., 2016)$. Some study showed that use cumin in feed effect on broiler performance (Rafiee, et al., 2014; Berrama, et al., 2017). This study was conducted to evaluate the use of cumin as feed supplement on some meat quality traits of the broiler chicken.

\section{Material \& Methods}

This study was conducted at the high education lab, Department of Animal Science, College of Agricultural Engineering Sciences, Sulaimani University (the source of broiler meat sample from College farm (Ross 30), cumin source from local market, origin India, in broiler feed. Feed composition and calculated chemical composition of experiment treatments showed in table (1). Chemical composition of cumin (Moisture content: 8\%, pH: 7.3, total ash: 7.5, acid insoluble ash: 18\%, alcohol soluble extractive: $6.58 \%$, water soluble extractive: $138 \%$ and ether soluble extractive: 11.44 and $12.36 \%$ in the wet and dry fruits. Crude protein 18.40 and $19.88 \%$, crude fibres 21.82 and $23.57 \%$, total carbohydrate 55.58 and $60.05 \%$ in the wet and dry fruits respectively) (Moawad, et al., 2015). Eight-day old broilers divided into four groups; each group contained three replicates ( 8 chicks per replicate) for 45 days. Treatments included; (T1), basal diet without cumin or control, (T2), basal diet with 3 g. cumin. $\mathrm{kg}^{-1}$ of diet, (T3), basal diet with $6 \mathrm{~g}$. cumin. $\mathrm{kg}^{-1}$ of diet, (T4), basal diet with $9 \mathrm{~g}$. cumin. $\mathrm{kg}^{-1}$ of diet. At the end of this experiment after the slaughtering all the chicks, samples were taken from the breast and thigh for some chemical and physical measurements.

\section{Chemical composition:}

Moisture, protein, fat and ash contents, estimated by method described by AOAC. \& Helrich (1990).

\section{Physic-chemical traits: \\ pH}

$\mathrm{pH}$ of muscle sample was measured by method described by Ibrahim et al. (2010).

\section{Cooking loss}

Cooking loss was determined according to Murphy \& Zerby (2004).

\section{Water holding capacity (WHC)}

Water holding capacity (WHC) was determined according to Wardlaw et al. (1973).

\section{Total volatile nitrogen (TVB.N)}

Estimated by method described by Malle \& Poumeyrol (1989).

\section{Thiobarbituric acid (TBA) value}

The TBA value was determined according to the method described by Witte et al. (1970).

\section{Determination of met-myoglobin percentage and myoglobin concentration}

Pigment of meat extract from muscles of each treatment was estimated using a modified procedure of Krzywicki (1982). 
Majid et al. / Basrah J. Agric. Sci., 33(1): 159-171, 2020

Table (1): Feed composition and calcualted chemical composition of experiment treatments $\cdots$

\begin{tabular}{|c|c|c|c|c|}
\hline \multicolumn{5}{|c|}{ 1-7 days } \\
\hline \multirow{2}{*}{ Feed Ingredients } & \multicolumn{4}{|c|}{$\% 100$} \\
\hline & \multicolumn{4}{|c|}{ T1 (Control) } \\
\hline Protein Conc. & \multicolumn{4}{|c|}{6} \\
\hline Yellow Corn & \multicolumn{4}{|c|}{51.7} \\
\hline Soybean Meal & \multicolumn{4}{|c|}{29} \\
\hline Wheat & \multicolumn{4}{|c|}{10} \\
\hline Sun Flower Seed Oil & \multicolumn{4}{|c|}{3} \\
\hline Salt & \multicolumn{4}{|c|}{0.3} \\
\hline Cumin & \multicolumn{4}{|c|}{0} \\
\hline Total & \multicolumn{4}{|c|}{100} \\
\hline \multicolumn{5}{|c|}{ Calcualted chemical composition } \\
\hline Crude Protein & \multicolumn{4}{|c|}{22} \\
\hline Energy Kcal. $\mathrm{kg}^{-1}$ & \multicolumn{4}{|c|}{3151} \\
\hline$\%$ Methionine & \multicolumn{4}{|c|}{0.64} \\
\hline \% Lysine & \multicolumn{4}{|c|}{1.22} \\
\hline$\%$ Fat & \multicolumn{4}{|c|}{5.6} \\
\hline$\%$ Fibres & \multicolumn{4}{|c|}{3.5} \\
\hline$\%$ Calcium & \multicolumn{4}{|c|}{0.47} \\
\hline \multicolumn{5}{|c|}{8 -21 days } \\
\hline \multirow{2}{*}{ Feed Ingredients } & \multicolumn{4}{|c|}{$\% 100$} \\
\hline & T1 (Control) & $\mathrm{T} 2$ & $\mathrm{~T} 3$ & $\mathrm{~T} 4$ \\
\hline Protein Conc. & 5 & 5 & 5 & 5 \\
\hline Yellow Corn & 56.9 & 56.9 & 56.6 & 56.4 \\
\hline Soybean Meal & 24.8 & 24.5 & 24.5 & 24.4 \\
\hline Wheat & 10 & 10 & 10 & 10 \\
\hline Sun Flower Seed Oil & 3 & 3 & 3 & 3 \\
\hline Salt & 0.3 & 0.3 & 0.3 & 0.3 \\
\hline Cumin & 0 & 0.3 & 0.6 & 0.9 \\
\hline Total & 100 & 100 & 100 & 100 \\
\hline \multicolumn{5}{|c|}{ Calcualted chemical composition } \\
\hline Crude Protein & 20 & 20 & 20 & 20 \\
\hline Energy Kcal/Kg & 3213 & 3207 & 3197 & 3188 \\
\hline$\%$ Methionine & 0.60 & 0.59 & 0.59 & 0.59 \\
\hline \% Lysine & 1.07 & 1.06 & 1.06 & 1.05 \\
\hline$\%$ Fat & 5.8 & 5.8 & 5.8 & 5.7 \\
\hline$\%$ Fibres & 3.4 & 3.4 & 3.4 & 3.3 \\
\hline
\end{tabular}


Majid et al. / Basrah J. Agric. Sci., 33(1): 159-171, 2020

\begin{tabular}{|c|c|c|c|c|}
\hline \multirow{2}{*}{$\%$ Calcium } & 0.40 & 0.40 & 0.40 & 0.40 \\
\hline \multirow{2}{*}{ Feed Ingredients } & \multicolumn{5}{|c|}{ 21 Days -Market Weight } \\
\cline { 2 - 5 } & T1 (Control) & T2 & T3 & T4 \\
\hline Protein Conc. & 5 & 5 & 5 & 5 \\
\hline Yellow Corn & 59.5 & 59.4 & 59.1 & 58.9 \\
\hline Soybean Meal & 22.2 & 22.0 & 22.0 & 21.9 \\
\hline Wheat & 10.0 & 10.0 & 10.0 & 10.0 \\
\hline Sun Flower Seed Oil & 3.0 & 3.0 & 3.0 & 3.0 \\
\hline Salt & 0.3 & 0.3 & 0.3 & 0.3 \\
\hline Cumin & 0.0 & 0.3 & 0.6 & 0.9 \\
\hline Total & 100 & 100 & 100 & 100 \\
\hline Crude Protein & 19.0 & 19.0 & 19.0 & 19.0 \\
\hline Energy Kcal/Kg & 3244 & 3236 & 3226 & 3217 \\
\hline \% Methionine & 0.59 & 0.59 & 0.58 & 0.58 \\
\hline \% Lysine & 1.00 & 0.99 & 0.99 & 0.99 \\
\hline \% Fat & 5.9 & 5.8 & 5.8 & 5.8 \\
\hline \% Fibre & 3.3 & 3.3 & 3.3 & 3.3 \\
\hline \% Calcium & 0.39 & 0.39 & 0.39 & 0.39 \\
\hline
\end{tabular}

\section{Minerals contents}

Mineral concentration estimated according to methods described by Hutton et al. (2014) and Rajib et al. (2016).

\section{Statistical Analysis}

All data were statistically analyzed by the Completely Randomized Design (CRD) by the SAS (Allison, 2010) system and the differences between the means of groups were estimated by Duncan Multiple Range Test (Duncan, 1955), statements of statistical significance are basing on $(\mathrm{P} \leq$ 0.01 ).

\section{Results \& Discussion}

The results in tables (2 and 3 ) revealed that supplementation with cumin did not significantly affect $(\mathrm{P} \leq 0.01)$ moisture and protein percentages of breast meat. However, moisture and protein percentages of thigh meat were significantly $(\mathrm{P} \leq 0.01)$ differed due to different treatments. Both lipids and ash percentages of were also significantly $\quad(\mathrm{P} \leq 0.01) \quad$ influenced by different supplement. The breast meat of chicks fed basal diet and $9 \mathrm{~g}$ cumin. $\mathrm{kg}^{-1}$ of diet recorded lowest protein percentage $(15.07 \%)$, while the meat of broiler chicks fed basal diet without cumin recorded highest percentage $(15.76 \%)$. The highest lipids and ash percentages recorded in breast and thigh meat of broiler chicks fed basal diet with $9 \mathrm{~g}$ cumin. $\mathrm{kg}^{-1}$ of diet $(7.54,9.39$, 3.33 and $3.35 \%$ respectively) while the lowest lipid and ash percentages recorded in 
breast and thigh meat of broiler chicks fed basal diet without cumin $(3.01,2.75,2.97$ and $2.53 \%$ ) respectively. The use of cumin not only improves the effectiveness and stimulation of bile acid production, also has led to a good increase in enzymes secreted by the pancreas and intestines such as amylase, trypsin, chymotrypsin and lipase (Rao et al., 2003; Muthamma et al., 2008). These positive secretions from the use of cumin seeds may improve the composition of carcass meat (Madhukar, 2013).

Table (2): Effect of supplementing cumin on moisture and protein composition of broiler chicks' breast and thigh meat (Mean \pm standard deviation).

\begin{tabular}{|c|c|c|c|c|}
\hline \multirow{2}{*}{ Treatments } & \multicolumn{2}{|c|}{ Moisture \% } & \multicolumn{2}{c|}{ Protein\% } \\
\cline { 2 - 5 } & Breast & Thigh & Breast & Thigh \\
\hline \multirow{2}{*}{ T1 } & $72.72 \pm 0.07$ & $67.64 \pm 1.36$ & $15.76 \pm 0.01$ & $15.71 \pm 0.01$ \\
& $\mathrm{a}$ & $\mathrm{c}$ & $\mathrm{a}$ & $\mathrm{a}$ \\
\hline \multirow{2}{*}{ T2 } & $73.99 \pm 0.34$ & $71.00 \pm 2.92$ & $15.72 \pm 0.01$ & $15.68 \pm 0.009$ \\
& $\mathrm{a}$ & $\mathrm{b}$ & $\mathrm{a}$ & $\mathrm{a}$ \\
\hline \multirow{2}{*}{ T3 } & $74.48 \pm 0.13$ & $73.52 \pm 0.02$ & $15.54 \pm 0.004$ & $15.5 \pm 0.001$ \\
& $\mathrm{a}$ & $\mathrm{a}$ & $\mathrm{a}$ & $\mathrm{a}$ \\
\hline \multirow{2}{*}{ T4 } & $74.80 \pm 0.07$ & $74.65 \pm 0.07$ & $15.07 \pm 0.57$ & $15.38 \pm 0.003$ \\
& $\mathrm{a}$ & $\mathrm{a}$ & $\mathrm{b}$ & $\mathrm{a}$ \\
\hline
\end{tabular}

*Mean with different letter $(a, b)$ among columns (treatment) are significantly differ $(\mathbf{P} \leq \mathbf{0 . 0 1})$.

Table (3): Effect of supplementing cumin on lipid and ash composition of broiler chicks' breast and thigh meat (Mean \pm standard deviation).

\begin{tabular}{|c|c|c|c|c|}
\hline \multirow{2}{*}{ Treatments } & \multicolumn{2}{|c|}{ Lipid\% } & \multicolumn{2}{|c|}{ Ash\% } \\
\hline & Breast & Thigh & Breast & Thigh \\
\hline T1 & $\begin{array}{c}3.01 \pm 0.004 \\
\mathrm{~d}\end{array}$ & $\begin{array}{c}2.75 \pm 0.02 \\
\mathrm{~d}\end{array}$ & $\begin{array}{c}2.97 \pm 0.003 \\
\mathrm{~d}\end{array}$ & $\begin{array}{c}2.53 \pm 0.004 \\
\mathrm{~d}\end{array}$ \\
\hline T2 & $\begin{array}{c}3.69 \pm 0.02 \\
\mathrm{c}\end{array}$ & $\begin{array}{c}3.81 \pm 0.10 \\
\mathrm{c}\end{array}$ & $\begin{array}{c}3.19 \pm 0.001 \\
\mathrm{c}\end{array}$ & $\begin{array}{c}2.86 \pm 0.001 \\
\mathrm{c}\end{array}$ \\
\hline T3 & $5.72 \pm 0.04 b$ & $\begin{array}{c}5.97 \pm 0.05 \\
b\end{array}$ & $\begin{array}{c}3.29 \pm 0.001 \\
b\end{array}$ & $\begin{array}{c}3.17 \pm 0.001 \\
b\end{array}$ \\
\hline T4 & $7.54 \pm 0.009 \mathrm{a}$ & $\begin{array}{c}9.39 \pm 0.13 \\
\mathrm{a}\end{array}$ & $\begin{array}{c}3.33 \pm 0.001 \\
\mathrm{a}\end{array}$ & $\begin{array}{c}3.35 \pm 0.002 \\
\mathrm{a}\end{array}$ \\
\hline
\end{tabular}

*Mean with different letter $(a, b)$ among columns (treatment) are significantly differ $(\mathbf{P} \leq \mathbf{0 . 0 1})$.

The results in table (4) showed that broiler chicks fed cumin impact significantly $(\mathrm{P} \leq 0.01)$ meat physical traits. The $\mathrm{pH}$ value of breast and thigh meat from broiler chicks that's fed with basal diet with $9 \mathrm{~g}$. cumin. $\mathrm{Kg}^{-1}$ of diet recorded highest values (7.25 and 7.47 respectively), while the lowest values were recorded in meat of broiler chicks fed basal diet without cumin, control groups (6.35 and 6.50 respectively).

The water holding capacity (WHC) results in table (3) revealed that chicks fed cumin showed significantly $(\mathrm{P} \leq 0.01)$ higher WHC \% of breast and thigh meat, the highest percentages recorded in breast and 
thigh meat of chicks from $\mathrm{T} 4$ groups (basal diet plus 9 g. cumin. $\mathrm{Kg}^{-1}$ of diet) which were (55.40 and 64.28\%) respectively. The lowest percentages recorded in breast and thigh meat of chick from T1 group (fed basal diet without cumin) which were (40.17 and 40.43\%) respectively.

The results of cooking loss percentages (CL) (Table 4), showed that breast and thigh meat of chicks fed feed supplement with cumin recorded lower CL\%, specifically in T4 group (basal diet plus 9 g. cumin. $\mathrm{Kg}^{-1}$ of diet) (36.84 and 36.32\%) respectively, which differ significantly with other treatment groups. The highest percentages recorded in breast and thigh meat of chicks from T1 groups (fed basal diet without cumin) (56.60 and 51.06\%) respectively.

Warriss (2000) described that high $\mathrm{pH}$ increases the water-binding because it affects the shrinkage of the contractile fibres, which might be the case in the present study, that meat sample has higher $\mathrm{pH}$ causes higher water holding capacity and lower cooking loss.

Table (4): Effect of Supplementing Cumin on some physical traits of broiler chicks' breast and thigh meat (Mean \pm standard deviation).

\begin{tabular}{|c|c|c|c|c|c|}
\hline \multirow{2}{*}{\multicolumn{2}{|c|}{ Traits }} & \multicolumn{4}{|c|}{ Treatment } \\
\hline & & \multirow{2}{*}{ 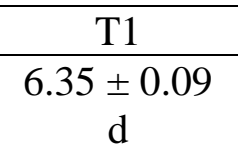 } & \multirow{2}{*}{$\begin{array}{c}\mathrm{T} 2 \\
6.68 \pm 0.002 \\
\mathrm{c}\end{array}$} & \multirow{2}{*}{$\begin{array}{c}\mathrm{T} 3 \\
6.96 \pm 0.06 \\
\mathrm{~b}\end{array}$} & \multirow{2}{*}{$\begin{array}{c}\mathrm{T} 4 \\
7.25 \pm 0.02 \\
\mathrm{a}\end{array}$} \\
\hline \multirow{2}{*}{ pH } & Breast & & & & \\
\hline & Thigh & $\begin{array}{c}6.50 \pm 0.006 \\
d\end{array}$ & $\begin{array}{c}6.89 \pm 0.009 \\
c\end{array}$ & $\begin{array}{c}7.13 \pm 0.02 \\
b\end{array}$ & $\begin{array}{c}7.47 \pm 0.19 \\
a\end{array}$ \\
\hline \multirow{2}{*}{ WHC\% } & Breast & $\begin{array}{c}40.17 \pm 0.03 \\
\mathrm{~d}\end{array}$ & $\begin{array}{c}44.07 \pm 0.42 \\
\mathrm{c}\end{array}$ & $\begin{array}{c}50.15 \pm 0.16 \\
b\end{array}$ & $\begin{array}{c}55.40 \pm 2.03 \\
a\end{array}$ \\
\hline & Thigh & $\begin{array}{c}40.43 \pm 0.23 \\
\mathrm{~d}\end{array}$ & $\begin{array}{c}49.51 \pm 0.02 \\
c\end{array}$ & $\begin{array}{c}51.69 \pm 1.25 \\
b\end{array}$ & $\begin{array}{c}64.28 \pm 2.20 \\
\mathrm{a}\end{array}$ \\
\hline \multirow{2}{*}{ CL\% } & Breast & $\begin{array}{c}56.60 \pm 3.68 \\
\mathrm{a}\end{array}$ & $\begin{array}{c}50.02 \pm 0.39 \\
b\end{array}$ & $\begin{array}{c}42.52 \pm 0.74 \\
c\end{array}$ & $\begin{array}{c}36.84 \pm 0.19 \\
\mathrm{~d}\end{array}$ \\
\hline & Thigh & $\begin{array}{c}51.06 \pm 0.56 \\
a\end{array}$ & $\begin{array}{c}45.65 \pm 1.13 \\
b\end{array}$ & $\begin{array}{c}39.80 \pm 0.90 \\
\mathrm{c}\end{array}$ & $\begin{array}{c}36.32 \pm 0.32 \\
\mathrm{~d}\end{array}$ \\
\hline
\end{tabular}

*Mean with different small letter $(a, b)$ among rows (treatment) are significantly differ $(P \leq 0.01)$.

The results of thiobarbuteric acids (TBA) and total volatile basic nitrogen (TVB.N) showed in table (5), Results revealed that fed broiler chicks feed supplemented with cumin significantly affect $(\mathrm{P} \leq 0.01)$ TBA and TVB.N values. Results of TBA showed that breast and thigh meat from treatments contain cumin recorded lowest values particularly meat from $\mathrm{T} 4$ group (basal diet plus 9 g. cumin. $\mathrm{kg}^{-1}$ of diet) which were 0.47 and $0.56 \mathrm{mg}$ MDA. $\mathrm{kg}^{-1}$ muscle in breast and thigh meat respectively., Breast and thigh meat from broiler chicks fed basal diet (T1 group) recorded highest TBA values $(0.70$ and $0.81 \mathrm{mg}$ MDA.kg muscle ${ }^{-1}$ ) respectively. The results of TVB-N values in table (5), revealed that breast and thigh meat of treatments contain cumin recorded better TVB-N values than meat from T1 (control 
group), the TVB-N values in meat from T4 group were (14.04 and $12.58 \mathrm{mgN} \cdot 100^{-1} \mathrm{~g}$ muscle) in breast and thigh meat TVB-N were 19.26 and $18.10 \mathrm{mg} \mathrm{N} \cdot 100^{-1} \mathrm{~g}$ muscle respectively. Gagandeep et al. (2003) mentioned that uses of cumin seed (2.5 and $5 \%$ of diet) in mice tended to increase superoxide dismutase, catalase and reduced glutathione. Foods containing respectively, while in breast and thigh meat of chicks fed basal diet ( $\mathrm{T} 1$ group) the

biologically active compounds that specialize in action against free radicals' help protect against cancer and may also help reduce cardiovascular and brain diseases in human (Miraliakbari \& Shahidi, 2008).

Table (5): Effect of Supplementing Cumin on some chemical traits of broiler chicks breast and thigh meat (Mean \pm standard deviation).

\begin{tabular}{|c|c|c|c|c|}
\hline \multirow{2}{*}{ Treatment } & \multicolumn{2}{|c|}{ TBA (mg MDA.kg-1 muscle) } & \multicolumn{2}{|c|}{ TVN (mg N.100-1 $\mathrm{g}$ muscle) } \\
\cline { 2 - 5 } & Breast & Thigh & Breast & Thigh \\
\hline T1 & $0.70 \pm 0.03 \mathrm{a}$ & $0.81 \pm 0.005 \mathrm{a}$ & $19.26 \pm 0.06 \mathrm{a}$ & $18.10 \pm 0.26 \mathrm{a}$ \\
\hline T2 & $0.63 \pm 0.001 \mathrm{~b}$ & $0.64 \pm 0.001 \mathrm{~b}$ & $16.00 \pm 0.009 \mathrm{~b}$ & $15.74 \pm 0.01 \mathrm{~b}$ \\
\hline T3 & $0.55 \pm 0.1 \mathrm{c}$ & $0.57 \pm 0.006 \mathrm{c}$ & $15.28 \pm 0.30 \mathrm{c}$ & $14.91 \pm 0.02 \mathrm{c}$ \\
\hline T4 & $0.47 \pm 0.008 \mathrm{~d}$ & $0.56 \pm 0.03 \mathrm{c}$ & $14.04 \pm 0.84 \mathrm{~d}$ & $12.58 \pm 0.58 \mathrm{~d}$ \\
\hline
\end{tabular}

*Mean with different letter (a, b) among columns (treatment) are significantly differ ( $\mathbf{P} \leq \mathbf{0 . 0 1})$.

The results of metmyoglobin and myoglobin represented in table (6). Results demonstrated that the use of cumin in chicks diet effect $(\mathrm{P} \leq 0.01) \quad$ met-myoglobin percentages and myoglobin values. The highest met- myoglobin percentage recorded in breast and thigh meat of broiler chicks from T1 group (basal diet) which were (49.64 and 58.65\%) respectively. In contrast the lowest percentages recorded in breast and thigh meat of chicks from T4 group (basal diet plus 9 g. cumin. $\mathrm{kg}^{-1}$ of diet) which were (30.82 and $36.16 \%)$ respectively.

The results of myoglobin value in table (6), displayed that breast and thigh meat of chicks fed basal diet plus 9 g. cumin. $\mathrm{kg}^{-1}$ of diet (T4 group) recorded highest value, which were (4.67 and $4.39 \mathrm{mg} . \mathrm{g}^{-1}$ muscle) respectively, in contrast the lowest value recorded in breast and thigh meat of chicks from T1 group (basal diet) which were 3.16 and $2.90 \mathrm{mg}^{-\mathrm{g}^{-1}}$ muscle) respectively. The colour of the product is very important in the purchase, especially when trading singular, and the colour of meat comes from the pigment of myoglobin which resulting from the oxidation of metaglobin (Hernández et al., 2015). Adding cumin as feed additive improved pigment stability compared with the control which may be due to their antioxidant activity and presence of some 
Majid et al. / Basrah J. Agric. Sci., 33(1): 159-171, 2020

Table (6): Effect of supplementing cumin on metmyoglobin and myoglobin value of broiler chicks' breast and thigh meat (Mean \pm standard deviation).

\begin{tabular}{|c|c|c|c|c|}
\hline \multirow{2}{*}{ Treatments } & \multicolumn{2}{|c|}{ Metmyoglobin \% } & \multicolumn{2}{c|}{ Myoglobin (mg.g ${ }^{-1}$ muscle) } \\
\cline { 2 - 5 } & Breast & Thigh & Breast & Thigh \\
\hline T1 & $49.64 \pm 0.70 \mathrm{a}$ & $58.65 \pm 0.99 \mathrm{a}$ & $3.16 \pm 0.05 \mathrm{~d}$ & $2.90 \pm 0.07 \mathrm{~d}$ \\
\hline T2 & $44.69 \pm 0.20 \mathrm{~b}$ & $46.97 \pm 0.24 \mathrm{~b}$ & $3.65 \pm 0.05 \mathrm{c}$ & $3.57 \pm 0.04 \mathrm{c}$ \\
\hline T3 & $39.44 \pm 0.54 \mathrm{c}$ & $43.00 \pm 1.50 \mathrm{c}$ & $3.99 \pm 0.007 \mathrm{~b}$ & $3.89 \pm 0.01 \mathrm{~b}$ \\
\hline T4 & $30.82 \pm 0.60 \mathrm{~d}$ & $36.16 \pm 0.33 \mathrm{~d}$ & $4.67 \pm 0.16 \mathrm{a}$ & $4.39 \pm 0.05 \mathrm{a}$ \\
\hline
\end{tabular}

*Mean with different letter (a, b) among columns (treatment) are significantly differ $(\mathrm{P} \leq 0.01)$.

bioactive principles in cumin (Madhukar, 2013). As seen in table (7), the cumin supplementation affect $(\mathrm{P} \leq 0.01)$ copper, nickel, zinc, iron, magnesium, phosphorus and Calcium concentrations in thigh meat. It also affect iron, magnesium, phosphorus, sodium and calcium concentrations in breast meat. For copper concentration, the highest concentration $(0.099 \mathrm{ppm})$ recorded in thigh meat fed cumin ( 9 g. cumin. $\mathrm{kg}^{-1}$ of diet), while the lowest concentration recorded by T1 (control, $0.085 \mathrm{ppm}$ ). Iron metabolism depends on the presence of copper and its deficiency leads to anaemia (McDowell, 2003). The highest nickel concentration recorded in thigh meat from broiler chicks of T4 (9 g. cumin. $\mathrm{kg}^{-1}$ of diet) treatment, $0.099 \mathrm{ppm}$, While the lowest concentration recorded in meat from broiler chicks of $\mathrm{T} 1$ (control, $0.085 \mathrm{ppm}$ ), zinc concentration recorded in thigh meat from broiler chicks of T4 (9 g. cumin. $\mathrm{kg}^{-1}$ of diet) highest concentration $(3.150 \mathrm{ppm})$, in contrast the meat from chicks of T2 (3 g. cumin. $\mathrm{kg}^{-1}$ of diet) recorded lowest concentration $(2.850$ $\mathrm{ppm})$, protein and carbohydrate metabolism, cell growth, and cell division in cell need Zinc (Lo et al., 2020). The highest iron concentration recorded in breast and thigh meat from chicks of T4 $\left(9 \mathrm{~g}\right.$. cumin. $\mathrm{kg}^{-1}$ of diet, 0.625 and $0.600 \mathrm{ppm}$ ) respectively, and lowest concentration recorded in breast and thigh meat of $\mathrm{T} 2$ ( $3 \mathrm{~g}$ cumin. $\mathrm{kg}^{-1}$ of diet, 0.505 and $0.405 \mathrm{ppm}$ ) respectively, the iron is important element for health, and iron deficiency is the common medicinal diseases (Abbaspour, et al., 2014). The highest magnesium concentration recorded in $\mathrm{T} 2$ ( $3 \mathrm{~g}$ cumin. $\mathrm{Kg}^{-1}$ of diet) breast meat and $\mathrm{T} 1$ (control) thigh meat (17.64 and $19.23 \mathrm{ppm})$ respectively, and lowest concentration recorded in T3 (6 g cumin. $\mathrm{kg}^{-1}$ of diet) breast meat and T2 ( $3 \mathrm{~g}$ cumin. $\mathrm{kg}^{-1}$ of diet) thigh meat (14.01 and $12.54 \mathrm{ppm}$ $\mathrm{ppm})$ respectively. The highest phosphorous concentration recorded in T2 $\left(3 \mathrm{~g}\right.$ cumin. $\mathrm{kg}^{-1}$ of diet) breast meat and T4 (9 g. cumin. $\mathrm{kg}^{-1}$ of diet) thigh meat (22.95 and $22.73 \mathrm{ppm}$ ) respectively and lowest concentration recorded in T1 (control) breast and thigh meat (16.12 and 14.48ppm) respectively. The highest breast sodium concentration recorded in meat of T1 (control, $83.23 \mathrm{ppm}$ ), while the lowest concentration recorded in T2 (3 g cumin. $\mathrm{kg}^{-1}$ of diet, (55.03 ppm). Calcium concentration recorded in breast 
and thigh meat from broiler chicks of T4 (9 g cumin. $\mathrm{kg}^{-1}$ of diet) highest concentration (9.26 and $8.27 \mathrm{ppm})$ respectively. In contrast the meat from chicks of $\mathrm{T} 1$ (control) recorded lowest concentration (4.45 and $4.17 \mathrm{ppm}$ ) respectively. The bone formation and neuromuscular function need calcium and phosphorus, blood clotting depends on calcium, while phosphor play important role in some function of blood (Zomrawi, 2013). Cumin consists of minerals such as potassium, sodium, calcium, iron, phosphorous and nutritional vitamins like thiamine, riboflavin, niacin, vitamins $\mathrm{A}$ and C (Moawad et al., 2015), this may causes different minerals concentration in meat from broiler feed with cumin in contrast to control groups.

Table (7): Effect of Supplementing cumin on mineral concentration (ppm) of broiler chicks breast and thigh meat (Mean \pm standard divation).

\begin{tabular}{|c|c|c|c|c|c|}
\hline Minerals & $\begin{array}{l}\text { Meat } \\
\text { type }\end{array}$ & $\mathrm{T} 1$ & $\mathrm{~T} 2$ & $\mathrm{~T} 3$ & $\mathrm{~T} 4$ \\
\hline \multirow{2}{*}{$\mathrm{Cr}$} & Breast & $0.085 \pm 0.007 \mathrm{a}$ & $0.099 \pm 0.001 \mathrm{a}$ & $0.099 \pm 0.001 \mathrm{a}$ & $0.120 \pm 0.029 \mathrm{a}$ \\
\hline & Thigh & $0.085 \pm 0.007 \mathrm{a}$ & $0.099 \pm 0.001 \mathrm{a}$ & $0.099 \pm 0.001 \mathrm{a}$ & $0.099 \pm 0.001 \mathrm{a}$ \\
\hline \multirow{2}{*}{$\mathbf{C u}$} & Breast & $0.085 \pm 0.007 \mathrm{a}$ & $0.099 \pm 0.001 \mathrm{a}$ & $0.099 \pm 0.001 \mathrm{a}$ & $0.099 \pm 0.001 \mathrm{a}$ \\
\hline & Thigh & $0.085 \pm 0.007 \mathrm{~b}$ & $0.099 \pm 0.001 \mathrm{a}$ & $0.099 \pm 0.001 \mathrm{a}$ & $0.099 \pm 0.001 \mathrm{a}$ \\
\hline \multirow{2}{*}{ Cd } & Breast & $0.045 \pm 0.007 \mathrm{a}$ & $0.049 \pm 0.000 \mathrm{a}$ & $0.049 \pm 0.001 \mathrm{a}$ & $0.049 \pm 0.001 \mathrm{a}$ \\
\hline & Thigh & $0.045 \pm 0.007 \mathrm{a}$ & $0.049 \pm 0.001 \mathrm{a}$ & $0.049 \pm 0.001 \mathrm{a}$ & $0.049 \pm 0.001 \mathrm{a}$ \\
\hline \multirow{2}{*}{$\mathbf{P b}$} & Breast & $0.10 \pm 0.0 \mathrm{a}$ & $0.099 \pm 0.001 \mathrm{a}$ & $0.110 \pm 0.014 \mathrm{a}$ & $0.099 \pm 0.001 \mathrm{a}$ \\
\hline & Thigh & $0.130 \pm 0.028 \mathrm{a}$ & $0.103 \pm 0.011 \mathrm{a}$ & $0.105 \pm 0.008 \mathrm{a}$ & $0.120 \pm 0.014 \mathrm{a}$ \\
\hline \multirow{2}{*}{$\mathbf{N i}$} & Breast & $0.085 \pm 0.007 \mathrm{a}$ & $0.099 \pm 0.001 \mathrm{a}$ & $0.115 \pm 0.021 \mathrm{a}$ & $0.099 \pm 0.001 \mathrm{a}$ \\
\hline & Thigh & $0.085 \pm 0.007 \mathrm{~b}$ & $0.099 \pm 0.001 \mathrm{a}$ & $0.099 \pm 0.001 \mathrm{a}$ & $0.099 \pm 0.001 \mathrm{a}$ \\
\hline \multirow{2}{*}{ Zn } & Breast & $3.250 \pm 0.212 \mathrm{a}$ & $3.40 \pm 0.424 \mathrm{a}$ & $3.100 \pm 0.566 \mathrm{a}$ & $2.800 \pm 0.424 \mathrm{a}$ \\
\hline & Thigh & $3.00 \pm 0.282 \mathrm{ab}$ & $2.850 \pm 0.707 \mathrm{~b}$ & $3.050 \pm 0.495 \mathrm{a}$ & $3.150 \pm 0.919 \mathrm{a}$ \\
\hline \multirow{2}{*}{$\mathbf{F e}$} & Breast & $0.535 \pm 0.077 \mathrm{ab}$ & $0.505 \pm 0.120 \mathrm{~b}$ & $0.520 \pm 0.085 \mathrm{a}$ & $0.625 \pm 0.064 \mathrm{a}$ \\
\hline & Thigh & $0.425 \pm 0.028 \mathrm{ab}$ & $0.405 \pm 0.078 \mathrm{~b}$ & $0.590 \pm 0.099 \mathrm{a}$ & $0.600 \pm 0.007 \mathrm{a}$ \\
\hline \multirow{2}{*}{ Mg } & Breast & $14.26 \pm 0.89 \mathrm{bc}$ & $17.64 \pm 0.79 \mathrm{a}$ & $14.01 \pm 0.06 \mathrm{c}$ & $15.85 \pm 0.28 \mathrm{bc}$ \\
\hline & Thigh & $19.23 \pm 0.43 \mathrm{a}$ & $12.54 \pm 0.65 c$ & $16.42 \pm 0.87 \mathrm{ab}$ & $14.71 \pm 2.19 b c$ \\
\hline \multirow[t]{2}{*}{$\mathbf{P}$} & Breast & $16.12 \pm 1.03 \mathrm{~b}$ & $22.95 \pm 1.91 \mathrm{a}$ & $19.73 \pm 2.01 \mathrm{ab}$ & $17.83 \pm 0.37 b$ \\
\hline & Thigh & $14.48 \pm 0.02 \mathrm{c}$ & $18.57 \pm 1.23 b$ & $19.48 \pm 0.12 b$ & $22.73 \pm 0.79 a$ \\
\hline \multirow{2}{*}{$\mathbf{N a}$} & Breast & $83.23 \pm 0.94 a$ & $55.03 \pm 1.34 \mathrm{~b}$ & $77.88 \pm 8.51 \mathrm{a}$ & $77.94 \pm 5.71 \mathrm{a}$ \\
\hline & Thigh & $90.92 \pm 4.27 \mathrm{a}$ & $68.59 \pm 13.43 \mathrm{a}$ & $73.78 \pm 6.03 \mathrm{a}$ & $79.03 \pm 4.17 \mathrm{a}$ \\
\hline \multirow{2}{*}{$\mathbf{C a}$} & Breast & $4.45 \pm 0.79 b$ & $6.45 \pm 1.80 \mathrm{ab}$ & $7.39 \pm 1.01 \mathrm{ab}$ & $9.26 \pm 0.78 \mathrm{a}$ \\
\hline & Thigh & $4.17 \pm 0.29 b$ & $4.53 \pm 0.62 b$ & $8.18 \pm 0.1 .71 \mathrm{a}$ & $8.27 \pm 1.84 \mathrm{a}$ \\
\hline \multirow[t]{2}{*}{$\mathbf{K}$} & Breast & $285.0 \pm 80.61 \mathrm{a}$ & $261.0 \pm 39.60 \mathrm{a}$ & $284.5 \pm 2.12 \mathrm{a}$ & $315.0 \pm 24.04 \mathrm{a}$ \\
\hline & Thigh & $317.0 \pm 21.21 \mathrm{a}$ & $286.0 \pm 8.48 . \mathrm{a}$ & $269.5 \pm 55.86 a$ & $299.0 \pm 14.14 \mathrm{a}$ \\
\hline
\end{tabular}

*Mean with different small letter $(a, b)$ among rows (treatment) are significantly differ ( $P \leq 0.01)$. 
Majid et al. / Basrah J. Agric. Sci., 33(1): 159-171, 2020

\section{Conclusion}

Cumin supplementation did not significantly affect moisture and protein percentages, and negatively effect on fat percentage and $\mathrm{pH}$ value, while impact positively on meat ash, water holding capacity and cooking loss percentages, TBA, TVB.N values, metmyoglobin, myoglobin value, copper, nickel, zinc, iron, magnesium, phosphorus and calcium concentrations of thigh meat and iron, magnesium, phosphorus, sodium and calcium concentrations of breast meat.

\section{Acknowledgements}

We would like to extend our special thanks to head and staff of Deprtment of Animal Sciences, College of Agricultural Engineering Sciences, Sulaimani University, for their supports and helps in this research.

\section{References}

Abbaspour, N.; Hurrell, R. \& Kelishadi, R. (2014). Review on iron and its importance for human health. J. Res. Med. Sci.: Off. J. Isfahan Univ. Med. Sci., 19(2): 164-174.

Akyildiz, S. \& Denli, M. (2016). Application of plant extracts as feed additives in poultry nutrition. SCI Papers, Ser. D. Ani. Sci.: LIX: 71-74.

Allison, P.D. (2010). Survival Analysis Using SAS: A Practical Guide, $2^{\text {nd }}$ ed. SAS Press, Cary, N. Carolina: 337 pp.

Association of Official Analytical Chemists \& Helrich, K. (1990). Official Methods of Analysis of the Association of Official Analytical Chemists. Arlington, V.A.: 771pp.
Berrama, Z.; Temim, S.; Souames, S. \& Ainbaziz, H. (2017). Growth performance, carcass and viscera yields, blood constituents and thyroid hormone concentrations of chronic heat stressed broilers fed diets supplemented with cumin seeds (Cuminum cyminum L.). Kafkas Univ Vet Fak Derg, 23(5): 735-742. https://doi.org/10.9775/kvfd.2017.17663.

De Martino, L.; De Feo, V.; Fratianni, F. \& Nazzaro, F. (2009). Chemistry, antioxidant, antibacterial and antifungal activities of volatile oils and their components. Nat. Prod. Commun., 4(12): 1741-1750. https://doi.org/10.1177/1934578X09004012 26

Diaz Carrasco, J.M.; Redondo, L.M.; Redondo, E. A.; Dominguez, J. E.; Chacana, A.P. \& Fernandez Miyakawa, M.E. (2016). Use of plant extracts as an effective manner to control Clostridium perfringens induced necrotic enteritis in poultry. BioMed. Res. Int., 2016: $1-15$. https://doi.org/10.1155/2016/3278359

Duncan, D. (1955). Multiple Range and Multiple F Tests. Biometrics, 11(1): 1-42. https://doi.org/10.2307/3001478. https://www.jstor.org/stable/3001478

Gagandeep, Dhanalakshmi, S.; Mendiz, E.; Rao, A.R. \& Kale, R.K. (2003). Chemopreventive effects of Cuminum cyminum in chemically induced forestomach and uterine cervix tumors in murine model systems. Nutr. Cancer, 47(2): 171-180. https://doi.org/10.1207/s15327914nc4702_ 10 
Majid et al. / Basrah J. Agric. Sci., 33(1): 159-171, 2020

Hernández, B.; Sáenz, C.; Alberdi, C. \& Diñeiro, J.M. (2015). Comparison between two different methods to obtain the proportions of myoglobin redox forms on fresh meat from reflectance measurements. J. Food Sci. Technol., 52(12): 8212-8219. https://doi.org/10.1007/s13197-015-1917-x

Hutton, L.A.; O'Neil, G.D.; Read, T.L.; Arest, Z.J.; Newton, M.E. \& Macpherson, J.V. (2014). Electrochemical X-ray fluorescence spectroscopy for trace heavy metal Analysis: Enhancing X-ray fluorescence detection capabilities by four orders of Magnitude. Anal. Chem., 86(9): 4566-4572. https://doi.org/10.1021/ac500608d.

Ibrahim, H.M.; Abou-Arab, A.A. \& Salem, F. M.A. (2010). Addition of some natural plant extracts and their effects on lamb patties quality. J. Food Technol., 8(3): 134142.

https://doi.org/10.3923/jftech.2010.134.142.

Johri, R. K. (2011). Cuminum cyminum and Carum carvi: An update. Pharmacogn. Rev., 5(9): 63-72. https://doi.org/10.4103/0973-7847.79101

Krzywicki, K. (1982). The determination of haem pigments in meat.Meat Sci., 7(1): 29$36 . \quad$ https://doi.org/10.1016/03091740(82)90095-X

Lassak, E. (1996), Encyclopedia of common natural ingredients used in food, drugs and cosmetics. Flavour Fragr. J., 11: 373-373. https://doi.org/10.1002/(SICI)1099-1026 (199611)11:6<373::AID-FFJ628>3.0.CO;25

Lo, M.N.; Damon, L.J.; Tay, J.W.; Jia, S. \& Palmer, A.E. (2020). Single cell analysis reveals multiple requirements for zinc in the mammalian cell cycle. Elife, 9: 1-24. https://doi.org/10.7554/eLife.51107

Mahmood, S.; Rehman, A.; Yousaf, M.; Akhtar, P.; Abbas, G.; Hayat, K. \& Shahzad, M.K. (2015). Comparative efficacy of different herbal plant's leaf extract on haematology, intestinal histomorphology and nutrient digestibility in broilers. Adv. Zool. Bot., 3(2): 11-16. https://doi.org/10.13189/azb.2015.030201

Madhukar, C. (2013). Phytochemical screening of cumin seeds extract. Rep. Opin., 5(1): 57-58.

https://doi.org/10.7537/marsroj050113.10

Malle, P. \& Poumeyrol, M. (1989). A new chemical criterion for the quality control of fish: Trimethylamine/total volatile basic nitrogen (\%). J. Food Prot., 52(6): 419-423. https://doi.org/10.4315/ 0362-028X52.6.419

McDowell, L.R. (2003). Minerals in Animal and Human Nutrition. $2^{\text {nd }}$ ed., Amsterdam, Elsevier Sci. 660pp.

Miraliakbari, H. \& Shahidi, F. (2008). Antioxidant activity of minor components of tree nut oils. Food Chem., 111(2): 421427.

https://doi.org/10.1016/j.foodchem.2008.04. 008

Moawad, S.A.; El-Ghorab, A.H.; Hassan, M., Nour-Eldin, H. \& El-Gharabli, M.M. (2015). Chemical and microbiological characterization of Egyptian cultivars for some spices and herbs commonly exported abroad. Food Nut. Sci., 6(07): 643-659. https://doi.org/10.4236/fns.2015.67068 


\section{Majid et al. / Basrah J. Agric. Sci., 33(1): 159-171, 2020}

Murphy, M.A. \& Zerby, H.N. (2004). Pre-rigor infusion of lamb with sodium chloride, phosphate, and dextrose solutions to improve tenderness. Meat Sci., 66(2): 343$349 . \quad$ https://doi.org/10.1016/S03091740(03)00109-8

Muthamma, M.K.S.; Dholakia, H.; Kaul T.P.; \& Vishveshwaraiah, P. (2008). Enhancement of digestive enzymatic activity by cumin (Cuminum cyminum L.) and role of spent cumin as a bionutrient. Food Chem., 110: 678- 683. https://doi.org/10.1016/j.foodchem.2008.02. 062

Rafiee, A.; Kheiri, F.; Rahimian, Y.; Faghani, M.; Valiollahi, M.R. \& Miri, Y. (2014). The effect of ginger root (Zingiber officinale) and cumin (Cuminum cyminum) powder on performance, some haematological traits and intestinal morphology of broiler chicks. Res. Opin. Anim. Vet. Sci., 4(2): 96-100

Rajib, A., SaifulIslam, A.T.M.; Ahmed R.; Rahman, T.; Rahman, A. \& Ismail A.B. (2016). Detection of chromium (Cr) using $\mathrm{X}$-ray fluorescence technique and investigation of $\mathrm{Cr}$ propagation from poultry feeds to egg and chicken flesh. Am. J. Eng. Res., 5(7): 243-247. http://www.ajer.org/papers/v5(07)/ZF05070 2430247.pdf

Rao, R.R.; Platel, K. \& Srinivasan, K. (2003). In vitro influence of spices and spice-active principles on digestive enzymes of rat pancreas and small intestine. Die Nahrung, 47(6): 408-412. https://doi.org/10.1002/food.200390091

Srinivasan K. (2018). Cumin (Cuminum cyminum) and black cumin (Nigella sativa) seeds: traditional uses, chemical constituents, and nutraceutical effects, Food Qual. $\quad$ Saf., $\quad 2(1)$ : 1-16. https://doi.org/10.1093/fqsafe/fyx031

Wardlaw, F.B.; McCaskill, L.H. \& Acton, J.C. (1973). Effect of postmortem muscle changes on poultry meat loaf properties. J. Food Sci., 38(3): 421-423. https://doi.org/10.1111/j.13652621.1973.tb01444.x

Warriss, P.D. (2000). Meat Science. An Introductory Text. New York: Cabi. Publ. Inc.: 312 pp. https://doi.org/10.4102/jsava.v71i4.731

Witte, V.C.; Krause, G.F. \& Bailey, M.E. (1970). A new extraction method for determining 2-thiobarbituric acid values of pork and beef during storage. J. Food Sci., 35(5): 582-585. https://doi.org/10.1111/j.13652621.1970.tb04815.x

Zomrawi, W.B. (2013). Response of broiler chicks and laying hens to dietary ginger (Ziangbir officinal) root powder. Ph.D. Thesis Univ. Khartou:. 147pp. 


\title{
تأثير إضافة الكمون (Cuminum cyminum L.) في بص صفات لحوم افراخ دجاج اللحم
}

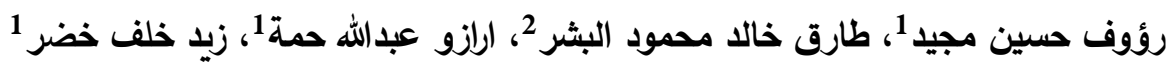

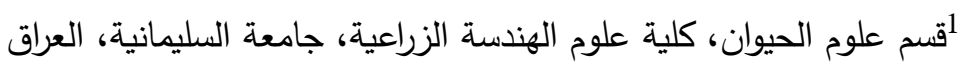

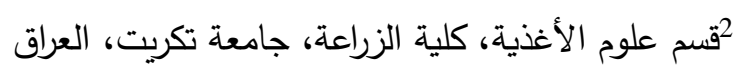

المستخلص: أجريت هذه الدراسة لتقيبم استعمال الكمون كمكل غذائي في بعض صفات جودة لحم دجاج اللحم. في عمر ثمانبة أيام ،

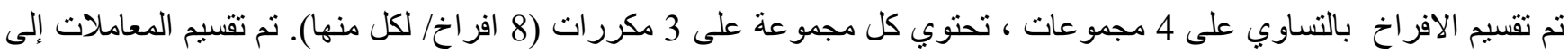

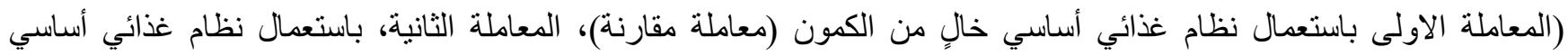

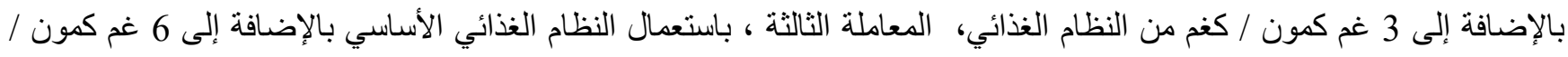

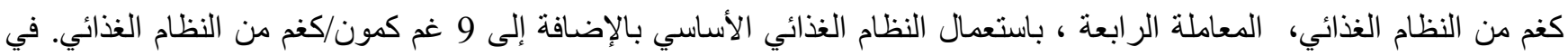

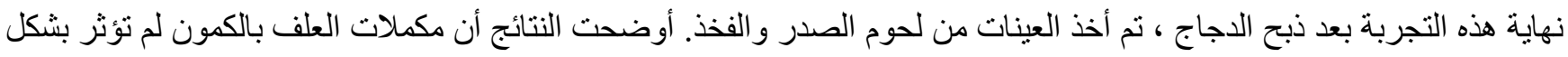

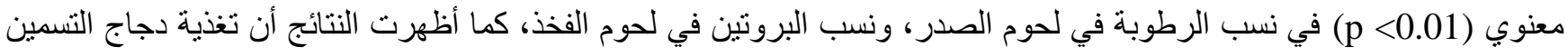

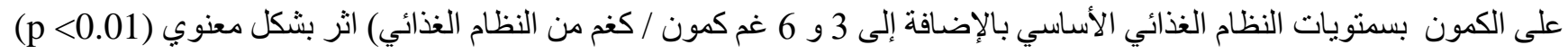

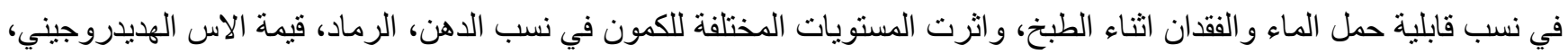

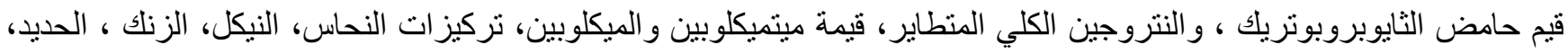

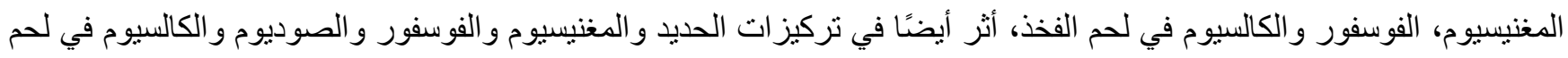

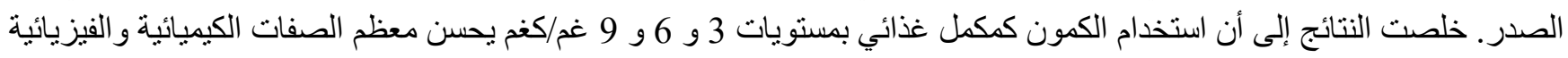
للحوم. الكلمات المفتاحية: الكمون، اضافة غذائية، افر اخ اللحم، صفات اللحم. 